Jerzy Cieślik*

\title{
Samozatrudnienie w Polsce na tle tendencji ogólnoświatowych: wyzwania w sferze polityki wspierania przedsiębiorczości i zabezpieczenia emerytalnego przedsiębiorców ${ }^{1}$
}

\begin{abstract}
Solo self-employment in Poland and worldwide: key challenges for entrepreneurial support and pension system for entrepreneurs: The article addresses key challenges in socio-economic policies caused by the growing share of self-employed without employees in the total workforce in developed market economy countries. It starts with the presentation of statistical data documenting recent trends in solo self-employment in Europe. Next, it discusses the policy implications of the growing population of solo self-employed, particularly the need for re-examination of the basic foundations of entrepreneurship and labour market policies. Key characteristics and pitfalls of the current public pension scheme for the self-employed in Poland are described in the second part of the article. It concludes with the recommendations regarding the reform of retirement benefits for this segment of the workforce.
\end{abstract}

Słowa kluczowe: $\quad$ samozatrudnienie, polityka wspierania przedsiębiorczości, zabezpieczenie emerytalne przedsiębiorców, przedsiębiorczość w Polsce Keywords: self-employment, entrepreneurship support policy, pension provision for entrepreneurs, entrepreneurship in Poland

* Profesor doktor hab., dyrektor Centrum Przedsiębiorczości w Akademii Leona Koźmińskiego • e-mail: cieslik@kozminski.edu.pl • https://orcid.org/oooo-0002-0611-432X

\section{Wstęp}

Kluczowym wyzwaniem dla współczesnej polityki wspierania przedsiębiorczości oraz polityki społeczno-gospodarczej w państwach wysoko rozwiniętych jest szybki wzrost liczby samozatrudnionych - osób prowadzących działalność

1 Artykuł prezentuje wyniki badań realizowanych w ramach projektu badawczego Samozatrudnienie w Polsce i na świecie nr 2015/19/B/HS4/00366 w Akademii Leona Koźmińskiego (ALK) finansowanego przez Narodowe Centrum Nauki. Stanowi rozwinięcie poglądów prezentowanych wcześniej przez autora w publikacjach prasowych i Alertach Centrum Przedsiębiorczości ALK. 
gospodarczą (pracujących na własny rachunek), którzy nie zatrudniają pracowników najemnych i taki stan traktują jako trwały ${ }^{2}$. Mimo podejmowanych na całym świecie badań zjawisko to jest jeszcze słabo rozpoznane. Znamienna jest tu wypowiedź wybitnego badacza amerykańskiego S.A. Shane'a: Najnowsze trendy [...] wskazuja, że musimy zrozumieć, dlaczego coraz mniej Amerykanów decyduje się uruchomić biznes z pracownikami. Bez odpowiedzi na to pytanie interpretacja danych dotyczacych mniejszych podmiotów będzie trudna ${ }^{3}$.

Celem artykułu jest pokazanie skali zjawiska samozatrudnienia w Polsce na tle tendencji ogólnoświatowych oraz wskazanie najważniejszych wyzwań, jakie zmiany w tym obszarze rodzą w zakresie polityki wspierania przedsiębiorczości i systemu zabezpieczenia emerytalnego przedsiębiorców ${ }^{4}$. W pierwszej części artykułu przedstawiono aktualne trendy występujące $\mathrm{w}$ tej dziedzinie na świecie i w Polsce. W części drugiej zaprezentowano występujące w obiegu publicznym sądy i przekonania, stanowiące fundament polityki wspierania przedsiębiorczości, które nie wytrzymują konfrontacji z rzeczywistością. Część trzecia poświęcona jest najważniejszym wyzwaniom w sferze polityki społeczno-gospodarczej w związku z rosnącym udziałem samozatrudnionych na rynku pracy (aktywności zawodowej). Chodzi o takie kwestie, jak zdefiniowanie na nowo pojęcia przedsiębiorcy i rodzajów aktywności gospodarczej wymagającej wsparcia. Czy nadal jest aktualny dychotomiczny (binarny) podział uczestników rynku pracy na pracowników i pracodawców. Czy samozatrudnionych należy zaliczyć do którejś z dwóch podstawowych grup, czy może uznać ich jako odrębną trzecią grupę na rynku pracy (aktywności zawodowej). Nowe wyzwania dotyczą także bezpieczeństwa socjalnego i ekonomicznego samozatrudnionych, zwłaszcza tych zależnych od jednego (wiodącego) kontrahenta (klienta).

W części czwartej przedstawiono analizę ewolucji wprowadzonego w $1999 \mathrm{r}$. systemu ubezpieczeń społecznych dla osób prowadzących działalność gospodarczą, w szczególności skutków rozszerzenia zakresu ulg dotyczących składek na ubezpieczenia emerytalno-rentowe (ulg ZUS) dla osób rozpoczynających taką działalność. W podsumowaniu zaprezentowano główne wnioski oraz

$2 \mathrm{~W}$ tej dziedzinie występuje pewne zamieszanie terminologiczne. Termin statystyczny self-employment obejmuje osoby prowadzące działalność gospodarczą, które zatrudniają bądź nie zatrudniają pracowników. Stąd w przypadku tej drugiej grupy często stosuje się termin solo self-employment. W Polsce stosuje się pojęcie samozatrudnienie jako odpowiednik solo self-employment i taką definicję przyjęto w niniejszym artykule.

3 A.S. Shane, Should We Count Non-Employer Businesses?, „Small Business Trends” 2012, June 25.

${ }^{4}$ Szczupłe ramy niniejszego artykułu nie pozwalają na szczegółowe uzasadnienie przedstawionych w nim tez i omówienie poglądów występujących w literaturze oraz danych empirycznych. Zainteresowanych czytelników odsyłam do monografii J. Cieślik, Przedsiębiorczość, polityka, rozwój, Wydawnictwo Akademickie SEDNO, Warszawa 2014. 
szczegółowe rekomendacje dotyczące pożądanych kierunków reformy systemu zabezpieczenia emerytalnego dla przedsiębiorców.

\section{Wzrost roli samozatrudnienia we współczesnych rozwiniętych gospodarkach}

Począwszy od lat 70. ubiegłego stulecia w państwach wysoko rozwiniętych obserwowany jest rosnący udział osób prowadzących działalność gospodarczą w całej populacji aktywnych zawodowo. Zjawisko to kojarzono z rewolucją w dziedzinie przedsiębiorczości na przełomie XX i XXI wieku i powstawaniem licznych małych, innowacyjnych podmiotów w nowoczesnych gałęziach gospodarki, opartych na technologiach informacyjnych i komunikacyjnych (ICT). Jednocześnie jednak wśród nowo zakładanych przedsiębiorstw coraz większy udział miały te, których właściciele nie planowali zatrudnienia pracowników. Przykładowo, w USA udział ten w 2000 r. wynosił 75\%, a w 2010 r. już 79\% ${ }^{5}$. Podobne zmiany wystąpiły w gospodarce niemieckiej: z 51\% w 2000 r. do 56\% w 2009 r. Cały przyrost podmiotów gospodarczych w Niemczech w latach 2000-2009 dotyczył samozatrudnionych ${ }^{6}$. Skala przedsiębiorczości bez pracowników (samozatrudnienia) jest na tyle poważna, że niektórzy badacze dostrzegają w niej czynnik równorzędny do zakładania innowacyjnych przedsiębiorstw, który doprowadził do wzrostu liczby podmiotów gospodarczych w państwach najwyżej rozwiniętych w końcu XX i na początku XXI wieku?

Wzrost znaczenia „przedsiębiorców solo” wiąże się z rozwojem usług, ale także rozwojem kooperacyjnych form działalności biznesowej, w tym zwłaszcza outsourcingu. Podobnie stosowanie elastycznych form zatrudnienia skłania do wyboru pracy na własny rachunek, nawet jeśli nie jest to wymagane przez kontrahenta. Tak będzie w przypadku pracy zdalnej prowadzonej z domu. Ze względu na praktyczne kwestie podatkowe, takie jak rozliczenie kosztów zakupu komputera czy kosztów bieżących, bardziej efektywne może okazać się zarejestrowanie działalności gospodarczej.

5 A.S. Shane, Should We Count Non-Employer Businesses?, op. cit.

${ }^{6}$ M. Fritsch, S.A. Kritikos, A. Rusakova, Who Starts a Business and Who Is Self-Employed in Germany, DIW Discussion Paper 1184, Berlin 2012.

7 S. Wennekers, A. Van Stel, M. Carree, R. Thurik, The relationship between entrepreneurship and economic development: Is it U-shaped?, „Foundations and Trends in Entrepreneurship" 2010, nr 6(3), s. 167-237; J. Cieślik, A. Van Stel, Comparative Analysis of Recent Trends in Private Sector Development in CEE Transition Economies, „Entrepreneurship Research Journal" 2014, nr 4(2), s. 205-235; A. Van Stel, S. Wennekers, G. Scholman, Solo self-employed versus employer entrepreneurs: Determinants and macro-economic effects in OECD countries, „Eurasian Business Review” 2014, nr 4(1), s. 107-136, https://doi.org/10.1007/s40821-0140003-Z. 
W okresie gorszej koniunktury i znacznego poziomu bezrobocia występują dodatkowe bodźce do poszukiwania możliwości obniżenia obciążeń podatkowych i zabezpieczenia społecznego zarówno dla samozatrudnionych, jak i pracodawców. Z kolei w warunkach niskiego bezrobocia i łatwego znalezienia pracy wiele osób, także o wysokich kwalifikacjach, preferuje samozatrudnienie, gdyż daje to większą autonomię oraz pozwala elastycznie łączyć aktywność zawodową z życiem rodzinnym czy realizacją własnych zainteresowań i hobby (wykres 1).

\section{Wykres 1. Czynniki wzrostu samozatrudnienia we współczesnej gospodarce}

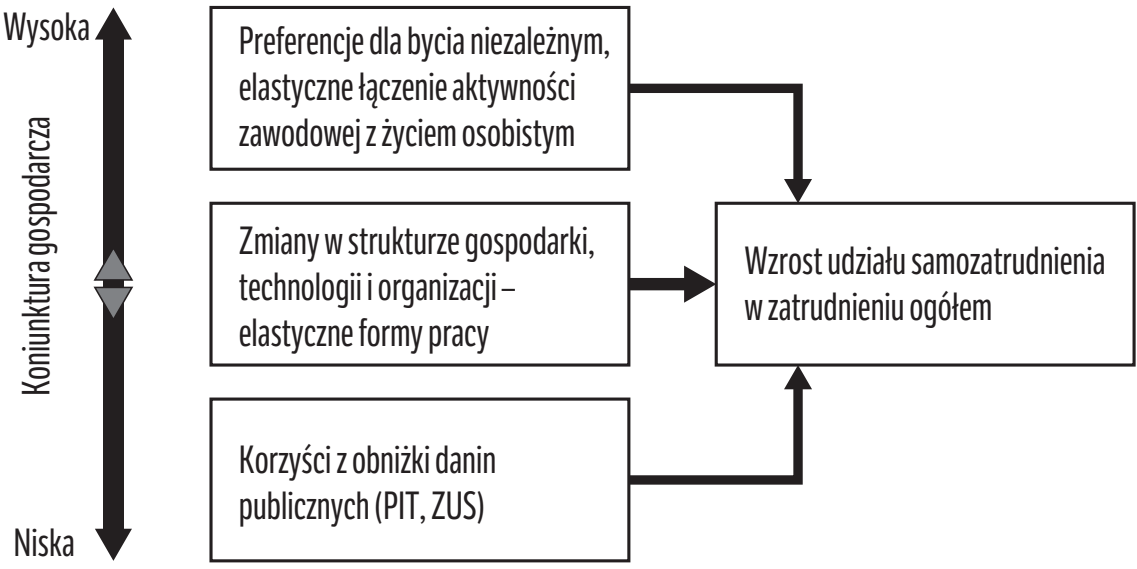

Powyższe zmiany znajdują odzwierciedlenie $\mathrm{w}$ strukturze podmiotów prowadzących działalność gospodarczą w formie zarejestrowanej (wykres 2). W państwach Unii Europejskiej 56\% zarejestrowanych podmiotów funkcjonuje bez pracowników i udział ten stale rośnie.

Jeśli chodzi o różnice między poszczególnymi państwami, to bardziej przydatne są dane statystyczne dotyczące aktywności ekonomicznej ludności (BAEL), bo eliminują skutki różnic w przepisach dotyczących obowiązku rejestracji działalności gospodarczej (wykres 3$)^{8}$. Tu udział samozatrudnionych jest jeszcze wyższy - średnia dla UE wynosi 69\%. Polska jest nieco poniżej tej średniej (66\%). Wśród państw o wyższym od średniego udziale samozatrudnienia znajdują się państwa śródziemnomorskie (Cypr, Grecja, Włochy), gdzie samozatrudnienie jest silnie zakorzenione kulturowo, ale także państwa przechodzące transformację ustrojową (Czechy, Litwa, Słowacja, Rumunia). O tym, że wysoki udział samozatrudnienia nie jest tylko udziałem krajów sła-

8 W większości państw, w tym w Polsce, tylko nieliczne formy aktywności gospodarczej mogą być realizowane bez formalnej rejestracji. Z kolei w Wielkiej Brytanii zakres działalności bez rejestracji jest bardzo szeroki. 
Wykres 2. Przedsiębiorstwa bez pracowników (solo) jako odsetek wszystkich podmiotów w 2016 r. (tylko podmioty zarejestrowane)

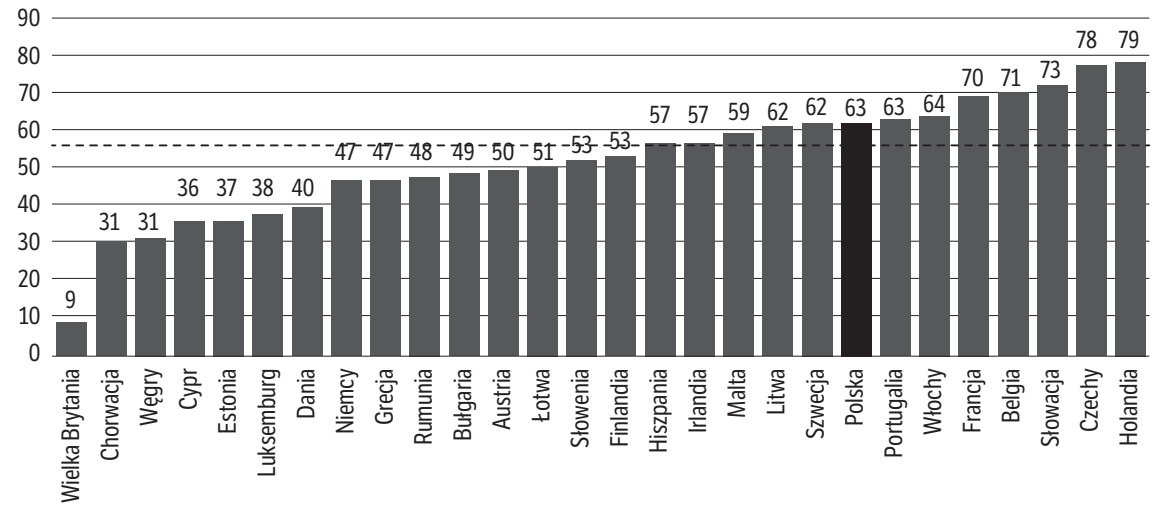

solo jako odsetek wszystkich podmiotów _ _ _- - średnia UE (56\%)

Źródło: na podstawie danych Eurostatu, https:/ec.europa.eu/eurostat/web/structural-business-statistics/ entrepreneurship/business-demography.

Wykres 3. Samozatrudnieni jako odsetek wszystkich pracujących na własny rachunek w 2017 r.

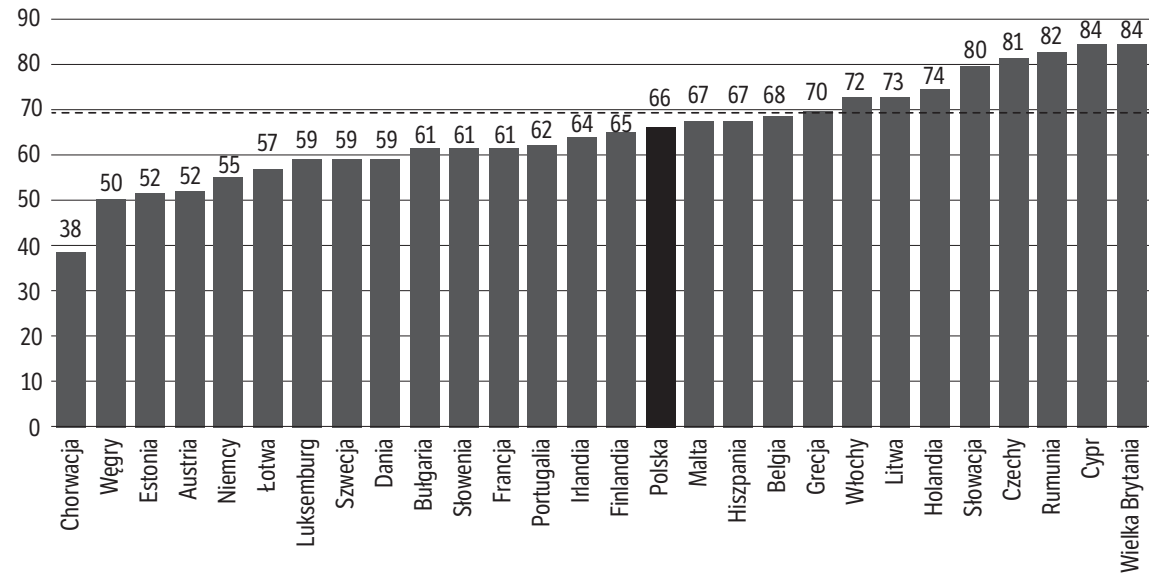

odsetek samozatrudnienionych pracujących na własny rachunek _ _. - - średnia UE (69\%)

Źródło: na podstawie danych Eurostatu (BAEL-LFS), https:/ec.europa.eu/eurostat/web/lfs/data/database. 


\section{Wykres 4. Pracodawcy i samozatrudnieni jako odsetek wszystkich pracujących w 2017 r. (dane BAEL z wyłączeniem rolnictwa)

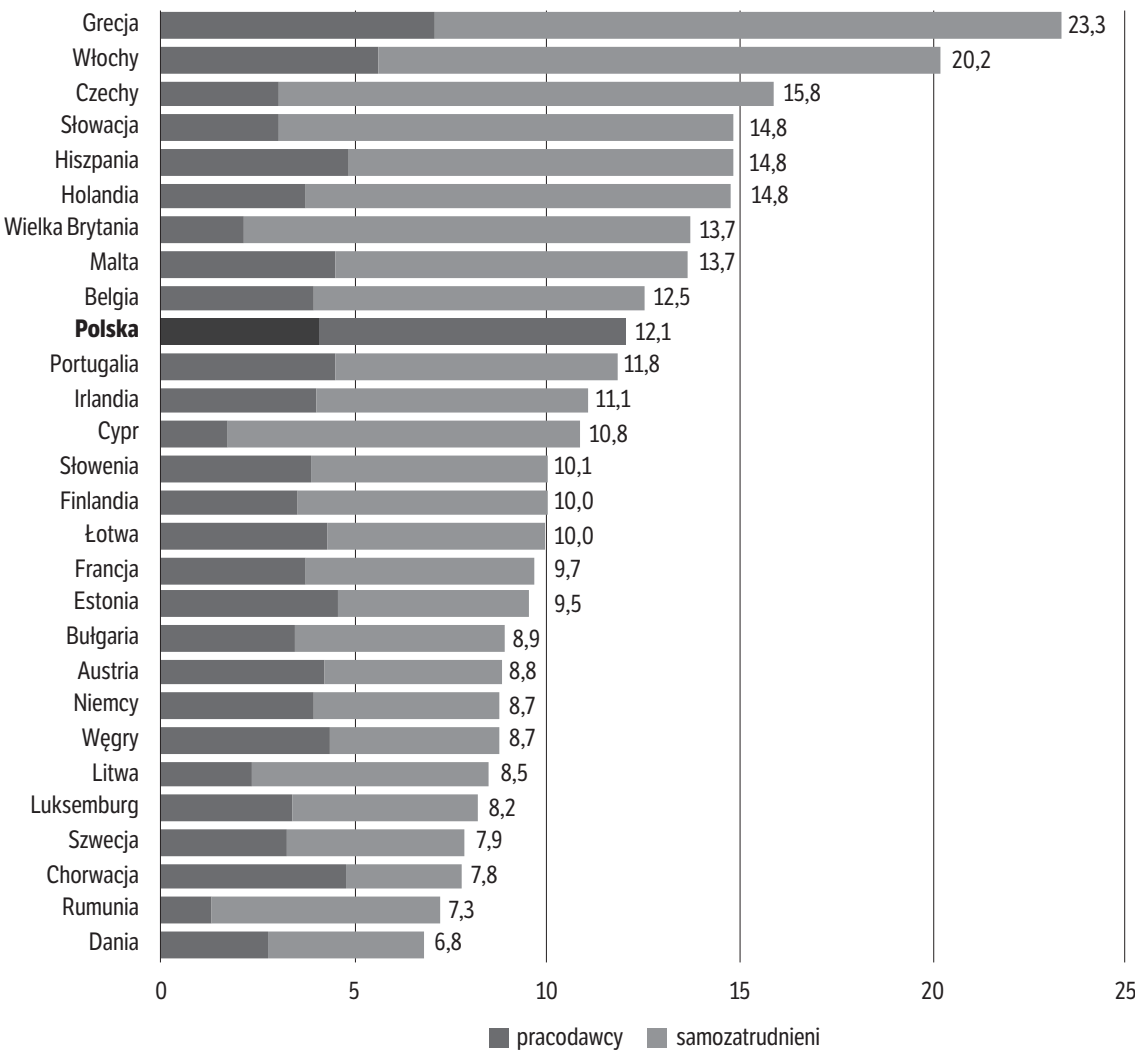

Źródło: na podstawie danych Eurostatu (BAEL-LFS), https://ec.europa.eu/eurostat/web/lfs/data/database.

biej rozwiniętych, świadczą przykłady takich państw, jak Belgia, Holandia czy Wielka Brytania, a poza kontynentem europejskim - Stany Zjednoczone, gdzie udział samozatrudnionych wśród prowadzących działalność gospodarczą jest bliski $80 \%$. Jednak z perspektywy państwa doganiającego, jakim jest Polska, trzeba brać pod uwagę fakt, że wspomniane państwa mają silny segment dużych korporacji, najczęściej wysoko umiędzynarodowionych, a także silny segment przedsiębiorstw małych i średnich. W takiej sytuacji samozatrudnienie stanowi jedynie uzupełnienie, niejako bufor na rynku pracy w okresach gorszej koniunktury. Polska znajduje się dopiero w trakcie budowania silnego sektora średnich i dużych przedsiębiorstw z kapitałem krajowym.

Powyższe zmiany w strukturze prowadzących działalność gospodarczą przekładają się na różnice w stopie przedsiębiorczości między państwami, mierzoną procentowym udziałem osób prowadzących działalność gospodarczą w ogólnej 
liczbie zatrudnionych (z wyłączeniem rolnictwa). Jak ilustruje wykres 4, różnice w stopie przedsiębiorczości w obrębie Unii Europejskiej są bardzo duże, ale w znacznym stopniu wynikają ze zróżnicowanej roli samozatrudnienia. Generalnie państwa o najwyższej stopie przedsiębiorczości to takie, które jednocześnie mają wysoki udział samozatrudnienia wśród osób prowadzących działalność gospodarczą. Gdyby wziąć pod uwagę tylko pracodawców, skala rozpiętości byłaby znacznie niższa.

\section{Samozatrudnieni a fundamenty polityki wspierania przedsiębiorczości}

To, jakie prawa i obowiązki mają samozatrudnieni z tytułu funkcjonowania w obrocie gospodarczym, jak są opodatkowani i jakie składki ZUS płacą, jest pochodną fundamentalnych zasad, na których opiera się polityka wspierania przedsiębiorczości. Powinny one bazować na solidnych podstawach naukowych i wiarygodnych danych empirycznych. W praktyce często ważniejsze są względy ideologiczne, a także tzw. prawdy obiegowe, głęboko zakorzenione w świadomości społecznej, postrzegane jako „oczywistośćc” i niepodlegające weryfikacji. Warto zilustrować to na przykładzie trzech szeroko rozpowszechnionych poglądów.

Im więcej przedsiębiorców (osób zajmujących się działalnością gospodarczą), tym lepiej dla gospodarki i społeczeństwa

Aktywność przedsiębiorcza to kwintesencja kapitalizmu i gospodarki wolnorynkowej, blokowana w dobie realnego socjalizmu. To oczywisty fundament zmian ustrojowych, jakie nastąpily po 1989 r. Stąd zasada, że „im więcej przedsiębiorców, tym lepiej", nie wydaje się budzić wątpliwości. Tymczasem międzynarodowe badania porównawcze pokazują, że w zdrowej, rozwiniętej gospodarce udział przedsiębiorców wśród ludności aktywnej ekonomicznie (stopa przedsiębiorczości) powinien być optymalny, a więc nie za mały, ale i nie za duży. To optimum w danym państwie zależy od osiągniętego poziomu rozwoju, ale także od czynników o charakterze kulturowym. Wspomniane badania wskazują również, że w Polsce w wymiarze ilościowym stopa przedsiębiorczości jest zbliżona do optymalnej ${ }^{9}$. Natomiast w porównaniu z bliskimi nam kulturowo wysoko rozwiniętymi państwami Europy Zachodniej niedostateczna jest jakość naszego sektora przedsiębiorstw w wymiarze techniczno-organizacyjnym oraz jeśli chodzi o skalę działania. W świetle powyższych ustaleń dążenie do dalszego zwiększania liczby osób zajmujących się działalnością gospodarczą w Polsce nie ma racjonalnego uzasadnienia.

9 Szerzej na ten temat zob. J. Cieślik, A. Van Stel, Comparative Analysis of Recent Trends, op. cit. 


\section{Nowo powstałe przedsiębiorstwa sa zakładane z myślą o rozwoju i zatrudnieniu pracowników $w$ przyszłości}

To przekonanie silnie zakorzenione w świadomości społecznej, będące kwintesencją pozytywnego myślenia o przedsiębiorcach, stanowi koronny argument, by zachęcać do zakładania nowych przedsiębiorstw zwłaszcza w okresie wysokiego bezrobocia. Ten sposób myślenia znajduje odzwierciedlenie w publicystycznych metaforach pakietu ulg dla początkujących przedsiębiorców zapisanych w tzw. Konstytucji biznesu: „pas startowy” lub „rozbiegówka”. Tymczasem badania empiryczne prowadzone przez autora wraz z zespołem na terenie Warszawy w latach 2015-2018 pokazują, że zdecydowana większość (2/3) założycieli startupów nie ma zamiaru się nigdzie „rozbiegać” i traktuje samozatrudnienie jako docelowy model biznesowy. Wśród pozostałych, którzy ewentualnie rozważają zatrudnienie pracowników w przyszłości, występuje zjawisko nadmiernego optymizmu. W efekcie spośród 250-300 tys. osób rozpoczynających w Polsce każdego roku działalność gospodarczą mniej niż 10\% ma szansę zostać pracodawcami w przyszłości. Podobne tendencje są obserwowane w innych państwach.

\section{Zachęty do zakładania nowych przedsiębiorstw prowadza do poprawy koniunktury gospodarczej i wzrostu PKB}

Pogląd ten został ukształtowany w państwach wysoko rozwiniętych w warunkach załamania koniunktury gospodarczej i poszukiwania narzędzi skutecznego wyprowadzania gospodarki z kryzysu. Gdy sektor korporacyjny nie jest w stanie wchłonąć znaczącej grupy bezrobotnych, każda forma ich aktywizacji przyczynia się do wzrostu PKB. Warto zatem tworzyć zachęty dla zakładania własnych przedsiębiorstw, bo ludzie, którzy znajdą w nich zatrudnienie, nie ustawią się w kolejce po zasiłki dla bezrobotnych. Jeśli nieliczni sami zostaną pracodawca$\mathrm{mi}$, to będzie to dodatkowa korzyść dla gospodarki.

W warunkach dobrej koniunktury i niskiego bezrobocia powyższa argumentacja staje się nieaktualna. Utrzymywanie ulg i preferencji dla rozpoczynających działalność gospodarczą faktycznie wspiera rachityczną formę tej działalności prowadzoną na niewielką skalę, o niskim wyposażeniu technicznym, niskiej produktywności i ograniczonych ambicjach rozwojowych właścicieli. Jak wskazano wcześniej, oczekiwanie, że początkujący przedsiębiorcy - beneficjenci ulg szybko rozwiną skrzydła, nie odzwierciedla realiów współczesnej gospodarki.

Preferencje dla rachitycznej działalności gospodarczej budzą szczególne zastrzeżenia, wobec znacznego zróżnicowania produktywności pracy w Polsce i nieproporcjonalnie dużego, w porównaniu z państwami najwyżej rozwiniętymi, zaangażowania pracujących w mało wydajnych podmiotach gospodarczych, głównie w mikroprzedsiębiorstwach ${ }^{10}$. Bardziej pogłębiona analiza

10 A. Łaszek, R. Trzeciakowski, Tylko 5,6 mln osób wytwarza połowę polskiego PKB, analiza 8/2018, Forum Odpowiedzialnego Rozwoju, Warszawa 2018, https://for.org.pl/ 
pokazuje, że istotne różnice w produktywności występują także w obrębie mikroprzedsiębiorstw, gdzie najniższą produktywność odnotowują podmioty nie zatrudniające pracowników najemnych (solo) (wykres 5). W takiej sytuacji zachęcanie do samozatrudnienia prowadzi wprost do obniżenia dynamiki wzrostu PKB. Tak będzie wtedy, gdy doświadczony informatyk uruchomi jednoosobową działalność gospodarczą, zamiast zatrudnić się w już istniejącym dużym przedsiębiorstwie IT, gdzie jego produktywność będzie ponadtrzykrotnie wyższa.

Wykres 5. Roczne przychody na 1 pracującego w 2015 r. według branż i klas wielkości przedsiębiorstw

(w tys. zł)

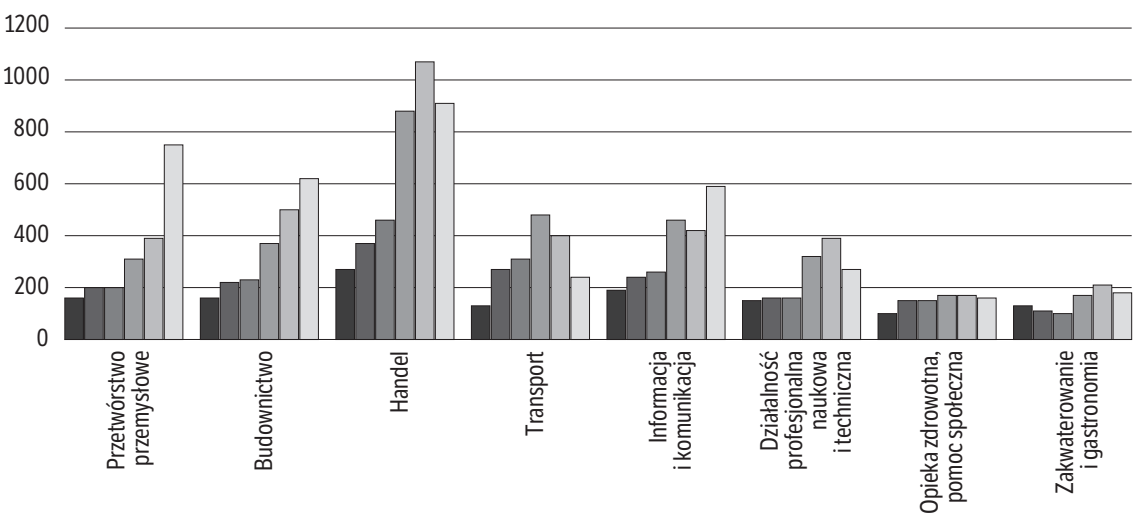

tylko właściciele $\square$ 2-5 pracujących $\square$ 6-9 pracujących $\square$ 10-49 pracujących $\square$ 50-249 pracujących $\square$ 250+ pracujących

Źródło: na podstawie danych GUS.

\section{Samozatrudnienie - współczesne wyzwania w sferze polityki społeczno-gospodarczej}

Jak uzasadniano wcześniej, podstawowe założenia, na których opiera się polityka wspierania przedsiębiorczości w Polsce, odzwierciedlają bardziej postawy ideologiczne, a także obiegowe sądy, a nawet iluzje, niż rzeczywiste procesy zachodzące w gospodarce. Niezbędne jest zatem przewartościowanie sposobu myślenia. Potrzeba przewartościowań dotyczy nie tylko polityki przedsiębiorczości, ale szerzej - polityki rynku pracy. Poniżej zaprezentowano najważniejsze wyzwania będące przedmiotem debaty w wielu państwach.

pl/a/6105, analiza-8/2018-tylko-5-6-mln-osob-wytwarza-polowe-polskiego-pkb. [dostęp: 2 lutego 2019 r.]. 


\section{Kto jest przedsiębiorcą?}

Konieczne zmiany należy zacząć od propozycji nowej definicji przedsiębiorcy, która powinna obejmować wyłącznie osoby zatrudniające pracowników na podstawie umowy o pracę. Jakkolwiek procesy zachodzące w przedsiębiorstwie wraz z rozszerzeniem skali działania następują w sposób ciągły, to nie ulega wątpliwości, że zatrudnienie pierwszego pracownika jest znaczącym, jakościowym etapem, obciążonym wyższym ryzykiem. W przypadku niepowodzenia koszty zamknięcia firmy, uregulowania zobowiązań wobec wierzycieli, w tym pracowników, mogą być bardzo poważne. Co innego dotyczy osoby prowadzącej działalność bez pracowników, przy minimalnym zaangażowaniu środków własnych, często bez odrębnego lokalu.

Z tym wiąże się potrzeba konsekwentnego przestrzegania fundamentalnej zasady, że przedsiębiorca wykonuje działalność gospodarczą w sposób ciągły. Zasada ta została potwierdzona w przepisach ogólnych ustawy - Prawo przedsiębiorców (art. 3), a następnie została złamana w art. 23, który daje możliwość samozatrudnionym zarejestrowanym w CEIDG do zawieszenia działalności na czas nieokreślony (wcześniej było to możliwe na okres 24 miesięcy). W nowej definicji przedsiębiorcy ta ewidentna sprzeczność zostałaby wyeliminowana.

\section{Jakq aktywność gospodarczq wspierać?}

W świetle wcześniej przedstawionych argumentów, w aktualnej sytuacji gospodarczej adresowanie pakietu ulg, w tym obniżonych składek ZUS, do wszystkich rozpoczynających działalność gospodarczą nie znajduje uzasadnienia. Tego typu wsparcie powinno być udzielane kandydatom na przedsiębiorców o ujawnionym potencjale rozwojowym - posiadającym własne środki, wiedzę i doświadczenie, a także rozsądny biznesplan. Kandydatom, którzy będą w stanie wykorzystać odpowiednio wygładzony i wydłużony „pas startowy”, by szybko rozwinąć działalność na większą skalę. To nie wyklucza szczególnych preferencji dla wybranych grup, gdzie ważne będę względy społeczne, np. osób niepełnosprawnych i szerzej - osób o nierównym statusie społecznym na rynku pracy.

Istotne różnice w produktywności pracy na niekorzyść podmiotów solo prezentowane wyżej stanowią dodatkowy argument przeciwko wspieraniu najsłabszego segmentu aktywności przedsiębiorczej w okresie dobrej koniunktury i niskiego bezrobocia. Kandydaci na „rachitycznych” przedsiębiorców mogą bowiem łatwo znaleźć zatrudnienie w już istniejących podmiotach oferujących dobrze wyposażone i zorganizowane stanowiska pracy gwarantujące wysoką produktywność.

Trzeba mieć świadomość, że we współczesnej gospodarce występują silne bodźce, które będą popychały w kierunku samozatrudnienia. W efekcie populacja „wolnych strzelców” w Polsce będzie się szybko zwiększać, podobnie jak w innych państwach wysoko rozwiniętych. Na obecnym etapie rozwoju przyspieszanie tego procesu poprzez dodatkowe bodźce i ulgi nie wydaje się uzasadnione. 


\section{Pozycja samozatrudnionych na rynku pracy}

W wielu państwach wysoko rozwiniętych toczy się dyskusja, w jaki sposób traktować samozatrudnionych jako uczestników rynku pracy. Ścierają się dwie koncepcje ${ }^{11}$. Pierwsza polega na utrzymaniu dychotomicznego (binarnego) podejścia i traktowaniu samozatrudnionych jako pracowników i/lub przedsiębiorców. Rodzi to liczne dylematy, o czym świadczą najnowsze rozwiązania przyjęte w Polsce, gdzie można mówić o legislacyjnym „rozdwojeniu jaźni”. Na gruncie ustawy - Prawo przedsiębiorców nie ulega wątpliwości, że samozatrudnieni prowadzący działalność gospodarczą to przedsiębiorcy. Ale wczytując się w zapisy nowelizacji ustawy o związkach zawodowych oraz niektórych innych ustaw uchwalonej 5 lipca 2018 r., łatwo zauważyć zamysł związkowców, by „przyłączyć" samozatrudnionych do siebie. Wprowadzono mianowicie kategorię "osoby wykonującej pracę zarobkową", w której mieszczą się samozatrudnieni i z tego tytułu nabywają pewne uprawnienia pracownicze, w tym możliwość zrzeszania się w związkach zawodowych.

W debacie publicznej rosnącą popularność zdobywa pogląd o potrzebie zmiany paradygmatu - uznanie, że samozatrudnienie to odrębna forma aktywności ekonomicznej obok pracy najemnej oraz prowadzenia przedsiębiorstwa zatrudniającego pracowników. W dyskusji na ten temat prowadzonej w państwach wysoko rozwiniętych, gdzie liczba „wolnych strzelców” wzrasta najszybciej (Wielka Brytania, USA), oni sami są tym żywotnie zainteresowani, tworząc krajowe i międzynarodowe organizacje reprezentujące ich interesy. Generalnie nie chcą być utożsamiani ani z pracownikami, ani z przedsiębiorcami, uważając, że stanowią trzecią siłę na rynku pracy czy, szerzej, aktywności zawodowej. W tym kierunku zmierzają rozwiązania legislacyjne w państwach wysoko rozwiniętych. Oprócz kwestii podatkowych i ubezpieczeń społecznych pojawiają się nowe wyzwania, jak chociażby kwestie szkoleń czy bezpieczeństwa i higieny pracy samozatrudnionych.

\section{Samozatrudnienie zależne}

Samozatrudnienie zależne to działalność gospodarcza prowadzona na rzecz jednego kontrahenta/klienta, który decyduje najczęściej o czasie pracy i sposobie realizacji zadań ${ }^{12}$. W debacie publicznej prowadzonej w wielu państwach uwaga skupia się na negatywnych skutkach samozatrudnienia zależnego i stąd powszechne są określenia takie jak „fikcyjne” czy „wymuszone”. Wprowadzone $\mathrm{w}$ wielu państwach regulacje, $\mathrm{w}$ tym także w Polsce, zmierzają do ograniczenia wymuszonych przejawów samozatrudnienia. Jeśli działalność gospodarcza ma

${ }_{11}$ Eurofound, Exploring self-employment in the European Union, Publications Office of the European Union, Luxembourg 2017.

12 J. Cieślik, Przedsiębiorczość, polityka, rozwój, op. cit.; C. Williams, F. Lapeyre, Dependent self-employment: trends, challenges and policy responses in the EU, „ILO Employment Working Paper" 2017, nr 228, https://doi.org/10.2139/ssrn.3082819. 
charakter fikcyjny, a wzajemne relacje są typowe dla stosunku pracy, istnieje możliwość potraktowania tych relacji dla celów podatkowych, ubezpieczenia społecznego czy ochrony praw pracowniczych, jak gdyby były one oparte na umowie o pracę.

Natomiast niedostateczną uwagę przywiązuje się do tych przejawów przedsiębiorczości zależnej, która opiera się na dobrowolnej umowie między stronami bądź jest nawet wymuszona przez pracownika. Ten ostatni przypadek dotyczy wysoko wykwalifikowanych fachowców, poszukiwanych na rynku pracy. Badacze i statystycy nie wypracowali dotychczas jednolitych metod pomiaru samozatrudnienia zależnego, co powoduje bardzo duże różnice w szacunkach skali tego zjawiska ${ }^{13}$. Najnowsze badania GUS wskazują, że wbrew obiegowym sądom skala samozatrudnienia zależnego jest $\mathrm{w}$ Polsce niewielka ${ }^{14}$.

\section{Bezpieczeństwo socjalne i ekonomiczne samozatrudnionych}

Zagrożenia w sferze bezpieczeństwa ekonomicznego i socjalnego wiążą się ze zjawiskiem samozatrudnienia zależnego. Osoby pracujące na własny rachunek zazwyczaj nie mają prawa do świadczeń socjalnych przyznawanych pracownikom zatrudnionym na podstawie umowy o pracę. W debacie publicznej dominuje pogląd, że warunki pracy powinny być godziwe niezależnie od formy zatrudnienia, czego pochodną są postulaty przyznania samozatrudnionym prawa do urlopu czy świadczeń z tytułu czasowej niezdolności do pracy ${ }^{15}$. W szerszym kontekście zagrożenia w sferze bezpieczeństwa ekonomicznego wynikają ze słabej pozycji przetargowej samozatrudnionych wobec klientów/zleceniobiorców. Wymusza to akceptację niskich stawek wynagrodzenia, co przekłada się na brak oszczędności umożliwiających utrzymanie standardu życiowego w przerwach między kolejnymi zleceniami.

Szczególny wymiar bezpieczeństwa ekonomicznego samozatrudnionych dotyczy ich zabezpieczenia emerytalnego. W przeciwieństwie do pracowników etatowych, którzy w państwach europejskich są objęci obowiązkowym ubezpieczeniem emerytalnym, samozatrudnieni są z tego obowiązku zwolnieni bądź podlegają mu w ograniczonym zakresie. Oczekuje się, że zadbają o swoją przyszłość, wykupując prywatne ubezpieczenia emerytalne, gromadząc oszczędności bądź inwestując środki np. w nieruchomościach, które będą generowały docho-

${ }_{13}$ Eurofound, Exploring self-employment in the European Union, op. cit.; C. Williams, F. Lapeyre, Dependent self-employment: trends, op. cit.; Eurostat, LFS 2017 ad-hoc module Self-employment, 2018, https://ec.europa.eu/eurostat/web/lfs/data/database.

${ }^{14}$ GUS, Pracujacy na własny rachunek w 2017 roku, Warszawa 2018.

15 C. Behrendt, Q.A. Nguyen, Innovative approaches for ensuring universal social protection for the future of work, ILO, Future of Work Research Paper Series, 2018, nr 1; S. Spasova, M. Wilkens, The social situation of the self-employed in Europe: labour market issues and social protection [w:] Social policy in the European Union: state of play 2018, European Trade Union Institute, Brussels 2018, s. 97-116. 
dy po zakończeniu aktywności zawodowej. Najnowsze badania przeprowadzone w Niemczech, a więc państwie o wysokiej „świadomości emerytalnej”, wskazują, że nie wszyscy samozatrudnieni są wystarczająco zapobiegliwi w tym zakresie ${ }^{16}$. Niepowodzenie biznesowe $\mathrm{i} /$ lub utrata zdrowia $\mathrm{w}$ okresie przedemerytalnym może prowadzić do ubóstwa i konieczności korzystania z pomocy społecznej. $\mathrm{W}$ ramach rozwiązań zmierzających do ograniczenia tego typu zagrożeń rozważa się objęcie samozatrudnionych obowiązkowym ubezpieczeniem emerytalnym.

Problemy i zagrożenia w sferze zabezpieczenia emerytalnego samozatrudnionych występują z dużym natężeniem w Polsce i wymagają pilnego podjęcia w debacie publicznej, która doprowadziłaby do odpowiednich rozwiązań legislacyjnych. W dalszej części artykułu zaprezentowano najważniejsze kwestie, a także kierunki proponowanych zmian.

\section{ZUS dla osób prowadzących działalność gospodarczą - ewolucja systemu i skutki wprowadzonych zmian}

Korzenie współczesnego oskładkowania ZUS dla osób prowadzących działalność sięgają roku 1999 i wprowadzonej w tym czasie kompleksowej reformy systemu ubezpieczeń społecznych. Brak możliwości weryfikacji faktycznych dochodów osiąganych przez zdecydowaną większość podmiotów gospodarczych, prowadzących działalność na bardzo niewielką skalę, spowodował, że zdecydowano się na minimalny ryczałt odpowiadający wysokości składek osoby zatrudnionej osiągającej dochód w wysokości $60 \%$ średniego miesięcznego wynagrodzenia w gospodarce. Z czasem wprowadzono ulgi (wykres 6). Najpierw był to tzw. mały ZUS I, czyli znacznie zmniejszone składki obowiązujące przez pierwsze dwa lata prowadzenia działalności. W ostatnich 2 latach wprowadzono dodatkowe ulgi: działalność nierejestrowaną, całkowite zwolnienie z ZUS przez pierwsze 6 miesięcy oraz wchodzący w 2019 r. „mały ZUS II”, obowiązujący przez 3 dodatkowe lata. Trzeba jednak mieć na uwadze, że tzw. normalny ZUS również zawiera element ulgi dla tych przedsiębiorców, których dochody przekraczają 60\% średniego miesięcznego wynagrodzenia, bowiem w przeciwieństwie do pracowników etatowych płacących składki proporcjonalnie do przychodów, mogą oni ograniczyć się tylko do minimalnego ryczałtu (i w ogromnej większości tak właśnie robią).

Wieloletnie stosowanie ulg w oskładkowaniu ZUS dla przedsiębiorców i rozszerzenie palety tych ulg w ostatnim okresie rodzi liczne skutki uboczne.

- Po pierwsze, nastąpił duży wzrost korzyści z arbitrażu, a więc powstała zachęta do odejścia od umów o pracę na rzecz jednoosobowej działalności

${ }^{16}$ K. Brenke, M. Beznoska, Solo-Selbständige in Deutschland - Strukturen und Erwerbsverläufe, Kurzexpertise für das Bundesministerium für Arbeit und Soziales, BMAS-Forschungsbericht nr 465, Berlin 2016. 


\section{Wykres 6. ZUS dla przedsiębiorców - paleta ulg w Konstytucji biznesu}

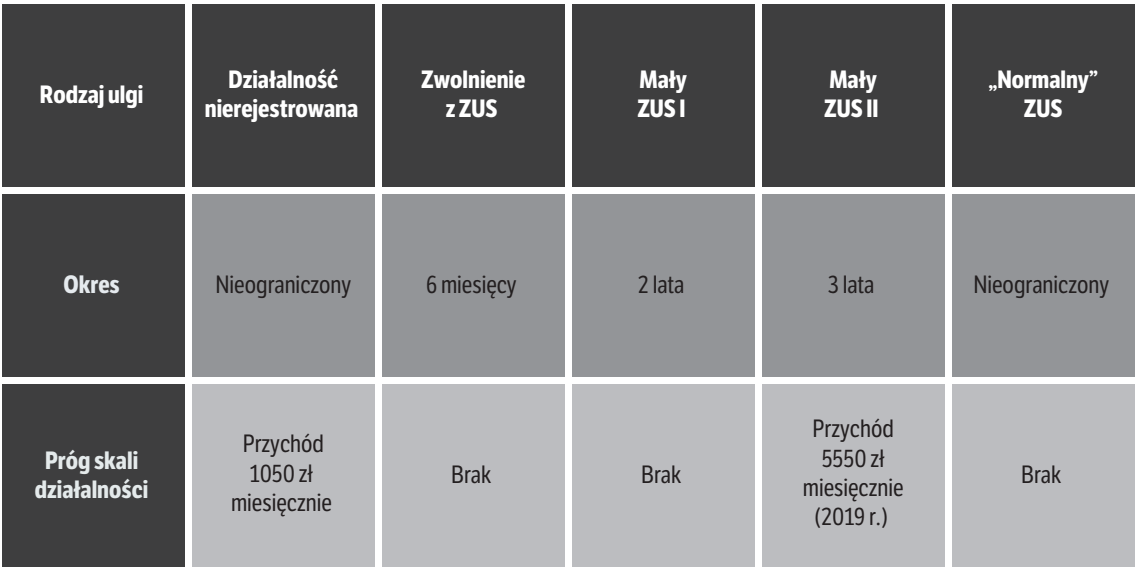

gospodarczej. Bardzo konkretną korzyścią jest zwolnienie z ZUS w fazie działalności nierejestrowanej i w ciągu pierwszych 6 miesięcy prowadzenia zarejestrowanej działalności. Łączny okres ulgowy zwiększył się z 2 do 5,5 lat (nie licząc działalności nierejestrowanej), tak więc skumulowane korzyści z przejścia na działalność gospodarczą mogą być znaczne. Dodatkowy silny bodziec do przejścia na samozatrudnienie zostanie uruchomiony, jeśli w 2020 r. będzie ostatecznie zniesiony górny próg naliczania składek ZUS dla zatrudnionych na umowę o pracę o rocznych dochodach przekraczających 30-krotność średniego miesięcznego wynagrodzenia. Będzie on szczególnie silny dla osób o wysokich dochodach. Zilustrowano to na przykładzie pracownika o wysokich kwalifikacjach o wynagrodzeniu brutto 15 tys. miesięcznie, czyli 180 tys. rocznie (tabela 1). Przy zatrudnieniu etatowym całkowity koszt jego wynagrodzenia będzie wynosił prawie 216,9 tys., bo trzeba dodatkowo uwzględnić składki ZUS opłacane przez pracodawcę. Po odliczeniu wszystkich danin publicznych (ZUS, NFZ i PIT) pracownikowi pozostanie 116,9 tys. zł, co stanowi tylko 53,8\% całkowitych kosztów zatrudnienia. Ale gdy przy tym samym całkowitym koszcie dla pracodawcy pracownik przejdzie na samozatrudnienie, jego dochód netto będzie wyższy w skali rocznej o prawie 50 tys. zł, stanowiąc $76,7 \%{ }^{17}$.

Przedstawione w tabeli 1 dane pokazują, że różnica na korzyść samozatrudnienia wynika w całości z niższych składek ZUS. Nominalny podatek PIT 19\% (przedsiębiorca) i według skali 18 i 32\% (pracownik) jest na zbliżonym poziomie. Różnica w wielkości podatku faktycznie odprowadzonego do urzędu

${ }_{17} \mathrm{~W}$ podanym przykładzie przyjęto założenie, że to pracownik przejmuje całość korzyści finansowych z tytułu przejścia na samozatrudnienie. W praktyce mamy zazwyczaj do czynienia z podziałem korzyści między pracownikiem a pracodawcą. 
skarbowego wynika $\mathrm{z}$ faktu, że pracownik płaci znacznie więcej na NFZ, a 86\% tego kosztu może odliczyć od podatku. Trzeba zastrzec, że prezentowane wyliczenia to przybliżone szacunki, bo nie są jeszcze znane parametry obciążeń dochodów z tytułu pracy i działalności gospodarczej w 2020 r. Nie ulega jednak wątpliwości, że dla osób o poszukiwanych na rynku kwalifikacjach, które mają szansę na wysokie dochody, roczne oszczędności w ZUS, odpowiadające cenie zakupu nowego samochodu średniej klasy, będą silnym bodźcem do przechodzenia na samozatrudnienie. Wątpliwe, czy uda się ten proces zatrzymać poprzez szczegółowe regulacje i nasilenie kontroli skarbowych i ZUS-owskich.

Tabela 1. Porównanie obciążeń z tytułu danin publicznych dochodów z pracy i w ramach działalności gospodarczej w 2020 r.*

\begin{tabular}{|c|c|c|c|c|c|}
\hline Etat & tys. zł & $\%$ & Działalność gospodarcza & tys. zł & $\%$ \\
\hline $\begin{array}{l}\text { Roczny koszt wynagrodzenia } \\
\text { pracownika dla pracodawcy }\end{array}$ & 216,9 & 100,0 & $\begin{array}{l}\text { Roczny dochód } \\
\text { (po odliczeniu kosztów) }\end{array}$ & 216,9 & 100,0 \\
\hline ZUS pracodawcy & 36,9 & 17,0 & & & \\
\hline Dochód brutto pracownika & 180,0 & 83,0 & & & \\
\hline ZUS pracownika & 24,7 & 11,4 & & & \\
\hline ZUS pracodawcy i pracownika & 61,5 & 28,4 & ZUS przedsiębiorcy & 10,9 & 5,0 \\
\hline NFZ 9\% & 14,0 & 6,4 & NFZ 9\% & 3,8 & 1,8 \\
\hline PIT według skali & 37,3 & & PIT liniowy $19 \%$ & 39,1 & \\
\hline $\begin{array}{l}\text { PIT po odliczeniu } \\
\text { NFZ } 7,75 \%\end{array}$ & 24,7 & 11,4 & $\begin{array}{l}\text { PIT po odliczeniu } \\
\text { NFZ } 7,75 \%\end{array}$ & 35,8 & 16,5 \\
\hline Dochód netto pracownika & 116,6 & 53,8 & Dochód netto z działalności & 166,3 & 76,7 \\
\hline
\end{tabular}

* Dane szacunkowe. Obliczenia prowadzone przy założeniu likwidacji górnego progu odprowadzania składek ZUS w wysokości 30-krotności średniej płacy krajowej.

Zniesienie górnego pułapu naliczania składek ZUS dla pracowników o wyższych dochodach powiększy rażącą niespójność obciążeń ZUS w przypadku zatrudnienia etatowego i w formie jednoosobowej działalności gospodarczej czy spółki osobowej. Te ostatnie formy są dość często wykorzystywane do prowadzenia przedsiębiorstw na dużą skalę, zatrudniających po kilkaset osób, co przekłada się na wysokie dochody ich właścicieli. Jak w nowej sytuacji wytłumaczyć, że przedsiębiorca, który osiąga dochody w wysokości 10-krotnej przeciętnej płacy, płaci na ZUS tak jak gdyby jego dochód wynosił $60 \%$ płacy?

- Po drugie, w środowisku osób, które prowadzą bądź prowadziły w przeszłości działalność gospodarczą, ukształtowało się negatywne nastawienie do składek ZUS jako niechcianej daniny publicznej, którą trzeba maksymalnie ograniczać, przeznaczając możliwie najniższą część dochodów na poczet przyszłej emerytury. W ciągu 20 lat funkcjonowania obecnego systemu corocznie rozpoczynało działalność w Polsce 250-300 tys. osób, z których tylko nieliczni utrzymali się na rynku. Można oszacować, że w całym tym okresie przygodę $\mathrm{z}$ własnym biznesem miało ponad $5 \mathrm{mln}$ osób. To duża grupa, biorąc pod uwage 
fakt, że w całym sektorze przedsiębiorstw pracuje ok. $10 \mathrm{mln}$ osób. O skali takich negatywnych postaw niech świadczy fakt, że według danych Ministerstwa Finansów mniej niż 1\% osób prowadzących działalność gospodarczą decyduje się na dobrowolne podwyższenie składki ZUS powyżej obowiązującego ryczałtu. Obecnie w Polsce jest wielu przedsiębiorców, którzy osiągają bardzo wysokie dochody. Z pewnością stać ich na dobrowolne podwyższenie płaconych składek, by uzyskać godziwą emeryturę w przyszłości, do wysokości odpowiadającej 2,5-krotnej średniego miesięcznego wynagrodzenia, a więc górnego pułapu naliczania składek ZUS dla zatrudnionych na podstawie umowy o pracę. Według danych Ministerstwa Finansów z takiej możliwości skorzystało w 2015 r. 149 przedsiębiorców.

- Po trzecie, $w$ rachunku ekonomicznym samozatrudnionych uwzględniane są przede wszystkim doraźne korzyści z tytułu obniżonych składek ZUS, natomiast negatywny skutek w postaci obniżonej emerytury w przyszłości pozostaje jako bliżej nieokreślona „zmienna rezydualna”, o wadze bliskiej zera. Najbardziej jest to widoczne w procesie przechodzenia $\mathrm{z}$ etatu na samozatrudnienie i świadczenie usług dla tego samego przedsiębiorstwa o zbliżonym zakresie. W praktyce rzadko jest to przymusowe „wypychanie" pracownika na samozatrudnienie. Pracodawca pokazuje pracownikowi skalę bieżących korzyści z obniżki podatku i składek ZUS oraz formułę podzielenia się tymi korzyściami. Dla pracownika to zazwyczaj atrakcyjna propozycja, bo nie bierze pod uwagę negatywnych skutków w postaci obniżonej emerytury w przyszłości. W aktualnej sytuacji na rynku pracy inicjatorami przejścia na samozatrudnienie są coraz częściej sami pracownicy, zwłaszcza przedstawiciele poszukiwanych zawodów. Paradoksalnie ten sposób myślenia jest wzmacniany przez rządową promocję systemu ulg w ramach „pasa startowego", gdzie o negatywnych skutkach wpływających na wysokość przyszłej emerytury mówi się mimochodem i na marginesie. To rodzi oczywisty dysonans z uruchamianym obecnie programem pracowniczych planów kapitałowych (PPK). O jego powodzeniu zadecyduje bowiem to, na ile uda się przekonać dużą część osób aktywnych zawodowo do rezygnacji z części bieżących dochodów na rzecz wyższej emerytury w przyszłości.

- Po czwarte, $\mathrm{w}$ wyniku rozszerzenia palety ulg w oskładkowaniu działalności gospodarczej zwiększy się liczba osób, które prowadzą bądź prowadziły w przeszłości działalność gospodarczą, a które nie zgromadzą odpowiednio wysokiego kapitału na indywidualnym koncie emerytalnym, by otrzymać emeryturę w zagwarantowanym ustawowo minimalnym wymiarze. W najgorszej sytuacji będą ci, którzy nie będą mieli wymaganego stażu pracy i liczby okresów składkowych, by nabyć uprawnienie do minimalnej emerytury. W tym kontekście szczególnie niebezpieczne jest korzystanie z bezskładkowych ulg, jak działalność nierejestrowana, 6-miesięczne zwolnienie z ZUS czy zawieszanie działalności gospodarczej na dłuższy okres. Doświadczenie pokazuje, że dużej części prowadzących działalność gospodarczą nie udaje się zgromadzić 
oszczędności mogących w wystarczającym stopniu uzupełnić kilkusetzłotowe emerytury. W przyszłości należy się liczyć z frustracją tej grupy emerytów, którzy mogą się czuć oszukani przez państwo, które zachęcało ich do podejmowania działalności gospodarczej i do korzystania z ulg w opłacaniu składek ZUS.

\section{Podsumowanie i rekomendacje}

Rosnący udział samozatrudnionych wśród osób prowadzących działalność gospodarczą, a w konsekwencji wzrost udziału tej grupy w ogólnej liczbie pracujących w państwach wysoko rozwiniętych stawia nowe wyzwania w sferze polityki przedsiębiorczości i polityki rynku pracy oraz wskazuje na potrzebę zasadniczych przewartościowań. Kierunki tych przewartościowań zasygnalizowano w części trzeciej artykułu. Przedstawione argumenty dowodzą, że w obszarze wspierania przedsiębiorczości mamy do czynienia z ewidentnym dysonansem, bowiem stosowane zachęty dla osób rozpoczynających działalność gospodarczą prowadzą do negatywnych konsekwencji dla beneficjentów w zakresie ich zabezpieczenia emerytalnego. Po 20 latach funkcjonowania obecnego systemu ZUS dla przedsiębiorców sytuacja dojrzała do generalnych zmian porządkujących ten system. Proponowane kierunki i zasady takiej reformy zostały przedstawione poniżej.

- Jako podstawową zasadę należy przyjąć, że składki na ZUS odprowadzane przez przedsiębiorców powinny pozwalać na zgromadzenie kapitału na indywidualnym koncie, który zapewniałby przyszłą emeryturę przynajmniej w zagwarantowanym ustawowo minimalnym wymiarze. To oznacza, że wszelkie ulgi w składkach ZUS dla przedsiębiorców nie powinny uszczuplać kapitału zgromadzonego na indywidualnym koncie przedsiębiorcy w stopniu uniemożliwiających wypłatę minimalnej emerytury w przyszłości. Poza wyjątkowymi sytuacjami, wynikającymi ze względów społecznych, nie ma uzasadnienia, by osoby decydujące się na nisko dochodową działalność gospodarczą były ciężarem dla przyszłych pokoleń. Zwłaszcza gdy mają alternatywę polegającą na zatrudnieniu w już istniejących przedsiębiorstwach i odprowadzaniu wyższych składek ZUS.

- System ulg w składkach ZUS dla osób rozpoczynających działalność gospodarczą powinien być oparty na instrumentach zwrotnych. Obecnie mamy do czynienia z bardzo szczególną formą finansowania tych ulg, gdzie podstawowym źródłem jest gromadzony przez przedsiębiorcę kapitał na indywidualnym koncie emerytalnym. Jednocześnie niższe wpłaty składek zwiększają kwotę dotacji z budżetu potrzebną, by zapewnić wypłatę bieżących świadczeń emerytalnych. Ulgi oparte na instrumentach zwrotnych są szeroko stosowane we wspieraniu fazy rozruchu nowych podmiotów gospodarczych (np. nisko- lub nieoprocentowane pożyczki na start) i nie ma uzasadnienia, by składki ZUS były tu wyjątkiem. Zatem, zamiast zwalniać bądź obniżać składki ZUS dla początkujących przedsiębiorców, należałoby stworzyć im możliwość odroczenia 
płatności składek do czasu aż rozwiną skrzydła. Po tym okresie będą musieli wyrównać niedopłacone składki, aby faktycznie uzupełnić kapitał na indywidualnym koncie, przynajmniej do wysokości gwarantującej minimalną emeryturę. Będzie to atrakcyjne rozwiązanie dla myślących poważnie o większym przedsiębiorstwie, zaś skutecznie zniechęci tych, których jedynym motywem dla rozpoczęcia jednoosobowego biznesu jest zaoszczędzenie na ZUS i na podatkach. Na nich czekają miejsca pracy w już istniejących, bardziej produktywnych przedsiębiorstwach, które chcą się dynamicznie rozwijać.

- Wdrożenie prawie 20 lat temu ryczałtowego systemu oskładkowania ZUS dla przedsiębiorców następowało w określonych warunkach techniczno-organizacyjnych, gdzie możliwości kontroli faktycznie uzyskiwanych dochodów małych przedsiębiorców przez aparat skarbowy i ZUS były bardzo ograniczone. Uznano zatem, że lepiej oprzeć cały system na ryczałcie. Obecnie aparat państwowy dysponuje znacznie lepszymi możliwościami technicznymi i organizacyjnymi, o czym świadczą osiągnięcia w egzekwowaniu podatków (w szczególności VAT). Należy zatem rozważyć odejście od ryczałtowych form oskładkowania ZUS dla działalności gospodarczej na rzecz kryterium dochodowego, podobnie jak w przypadku osób zatrudnionych na podstawie umowy o pracę.

Przy tak radykalnej zmianie systemu zabezpieczenia emerytalnego dla osób prowadzących działalność gospodarczą można pójść o krok dalej i wrócić do idei ujednolicenia obciążeń publicznych - podatków, ubezpieczeń społecznych, a także ubezpieczeń zdrowotnych ${ }^{18}$ dla wszystkich form aktywności ekonomicznej. Chodzi o koncepcje ,jednolitej daniny”, autorstwa P. Wojciechowskiego ${ }^{19}$. Paradoksalnie fakt, że w społeczeństwie znajduje się wielomilionowa grupa byłych i aktualnych przedsiębiorców, którzy są generalnie niechętni składkom ZUS, może być tu dodatkowym argumentem. Skoro ta znacząca grupa nie postrzega szczególnego związku między opłacaniem składek ZUS a przyszłą emeryturą i traktuje składki jako dodatkowy „podatek”, to włączenie składek do „jednolitej daniny" będzie dla nich naturalne i w pełni zrozumiałe. W aktualnej sytuacji demograficznej w Polsce długofalowa stabilność systemu ubezpieczeń społecznych będzie zależała od tego, w jakim stopniu uda się przekonać obywateli do przeznaczenia (odłożenia) większej części bieżących dochodów na poczet przyszłych emerytur. Temu powinny służyć instrumenty ekonomiczno-finansowe, ale także działania o charakterze informacyjnym, przekonywujące do zmiany w świadomości i postawach społecznych. W przypadku samozatrudnionych obserwowane jest niepokojące zjawisko ograniczonej „świadomości emerytalnej", którzy deklarują, że nie liczą na ZUS, a o przyszłość emerytalną zadbają sami. Jednak znikoma skłonność do dobrowolnego podniesienia składki

18 System ubezpieczeń zdrowotnych dla przedsiębiorców także wymaga kompleksowego uregulowania. Szczupłe ramy artykułu nie pozwalają na rozwiniętą analizę tej kwestii.

19 P. Wojciechowski, Epilog jednolitej daniny, „Rzeczpospolita” z 2 lutego 2017 r. 
emerytalnej w ZUS ponad minimalny ryczałt wskazuje na pewną niefrasobliwość w tej dziedzinie. Zmiana świadomości emerytalnej tej grupy to kluczowy element reformy całego systemu.

\section{Bibliografia}

Behrendt C., Nguyen Q.A., Innovative approaches for ensuring universal social protection for the future of work, ILO, Future of Work Research Paper Series, 2018, nr 1.

Brenke K., Beznoska M., Solo-Selbständige in Deutschland - Strukturen und Erwerbsverläufe, Kurzexpertise für das Bundesministerium für Arbeit und Soziales, BMAS-Forschungsbericht nr 465, Berlin 2016.

Cieślik J., Przedsiębiorczość, polityka, rozwój, Wydawnictwo Akademickie SEDNO, Warszawa 2014.

Cieślik J., Van Stel A., Comparative Analysis of Recent Trends in Private Sector Development in CEE Transition Economies, „Entrepreneurship Research Journal” 2014, nr 4(2), https://doi.org/10.1515/erj-2013-0054.

Eurofound, Exploring self-employment in the European Union, Publications Office of the European Union, Luxembourg 2017.

Eurostat, LFS 2017 ad-hoc module Self-employment, 2018, https://ec.europa.eu/eurostat/ web/lfs/data/database.

Fritsch M., Kritikos A.S., Rusakova A., Who Starts a Business and Who Is Self-Employed in Germany, DIW Discussion Paper 1184, Berlin 2012, https://doi.org/10.2139/ ssrn.2006494.

GUS, Pracujący na własny rachunek w 2017 roku, Warszawa 2018.

Łaszek A., Trzeciakowski R., Tylko 5,6 mln osób wytwarza połowe polskiego PKB, analiza 8/2018, Forum Odpowiedzialnego Rozwoju, Warszawa 2018, https://for.org. $\mathrm{pl} / \mathrm{pl} / \mathrm{a} / 6105$, analiza-8/2018-tylko-5-6-mln-osob-wytwarza-polowe-polskiego-pkb.

Shane A.S., Should We Count Non-Employer Businesses?, „Small Business Trends” 2012, June 25.

Spasova S., Wilkens M., The social situation of the self-employed in Europe: labour market issues and social protection [w:] Social policy in the European Union: state of play 2018, European Trade Union Institute, Brussels 2018.

Van Stel A., Wennekers S., Scholman G., Solo self-employed versus employer entrepreneurs: Determinants and macro-economic effects in OECD countries, „Eurasian Business Review" 2014, nr 4(1), https://doi.org/10.1007/s40821-014-0003-z.

Wojciechowski P., Epilog jednolitej daniny, „Rzeczpospolita” z 2 lutego 2017 r.

Wennekers S., Van Stel A., Carree M., Thurik R., The relationship between entrepreneurship and economic development: Is it U-shaped?, „Foundations and Trends in Entrepreneurship" 2010, nr 6(3).

Williams C., Lapeyre F., Dependent self-employment: trends, challenges and policy responses in the EU, „ILO Employment Working Paper” 2017, nr 228, https://doi. org/10.2139/ssrn.3082819. 


\section{Akty prawne}

Ustawa z 6 marca 2018 r. - Prawo przedsiębiorców, t.j. Dz.U. 2019 poz. 1292, ze zm.

Ustawa z 5 lipca 2018 r. o zmianie ustawy o związkach zawodowych oraz niektórych innych ustaw, Dz.U. poz. 1608.

\section{Strony internetowe}

Https://ec.europa.eu/eurostat/web/lfs/data/database.

Https://ec.europa.eu/eurostat/web/structural-business-statistics/entrepreneurship/ business-demography. 